$1-1-1984$

\title{
Consumers' opinions, attitudes and use of direct markets in West Virginia
}

Kitty Lou Blackburn

Follow this and additional works at: https://researchrepository.wvu.edu/ wv_agricultural_and_forestry_experiment_station_bulletins

\section{Digital Commons Citation}

Blackburn, Kitty Lou, "Consumers' opinions, attitudes and use of direct markets in West Virginia" (1984). West Virginia Agricultural and Forestry Experiment Station Bulletins. 686.

https://researchrepository.wvu.edu/wv_agricultural_and_forestry_experiment_station_bulletins/580 @ WVU. It has been accepted for inclusion in West Virginia Agricultural and Forestry Experiment Station Bulletins by an authorized administrator of The Research Repository @WVU. For more information, please contact ian.harmon@mail.wvu.edu. 

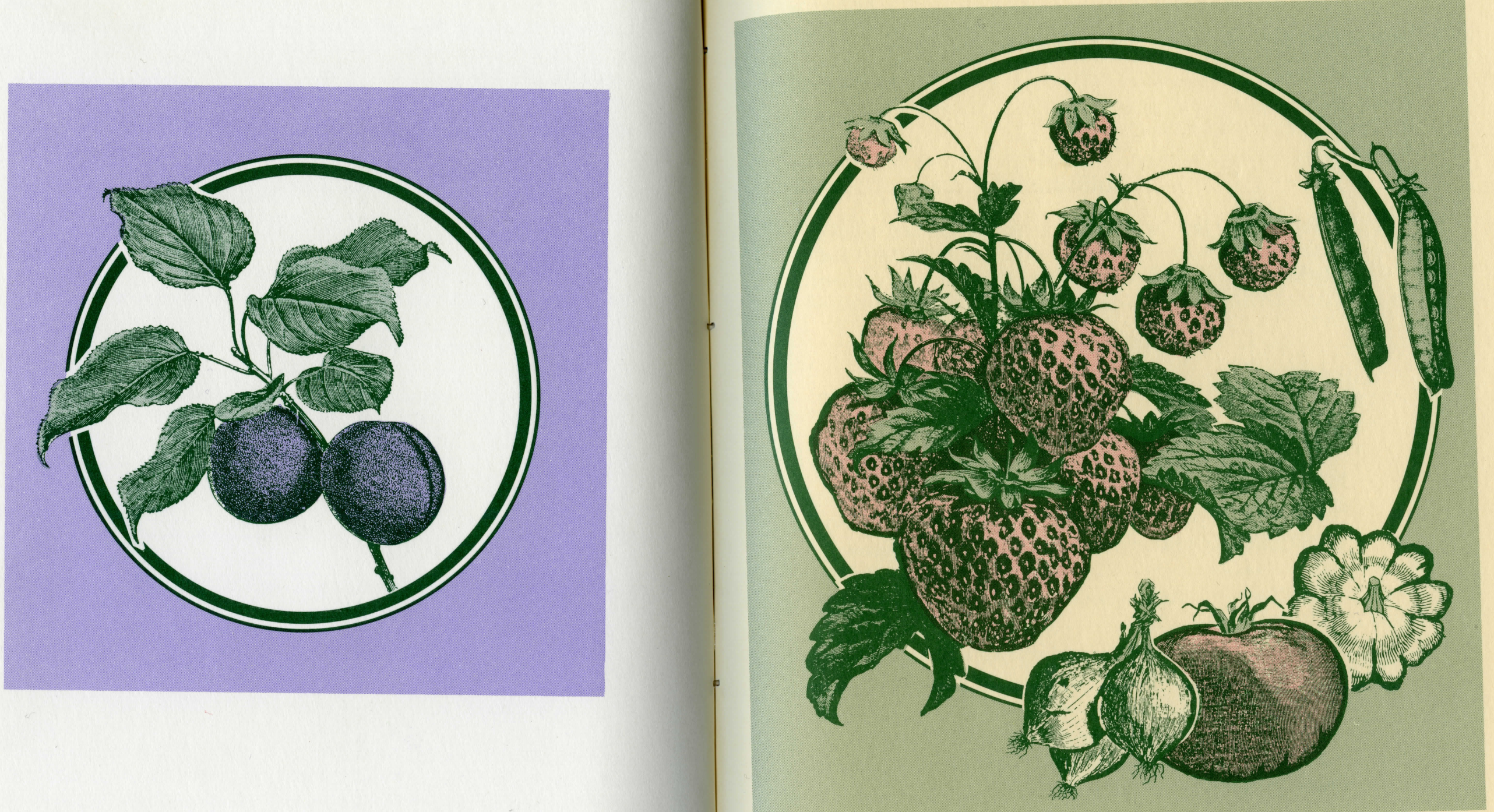

CONSUMERS' OPINIONS, ATTITUDES AND USE OF DIRECT MARKETS IN WEST VIRGINIA 


\section{Authors}

Robert L. Jack is agricultural economist and interim chairman, Division of Resource Management; Kitty Lou Blackburn was a graduate assistant in agricultural economics.

\section{Acknowiedgments}

This research was funded by the Science and Education Administration, Agricultural Research Service, U.S. Department of Agriculture, Washington, D.C.

The authors appreciated the help Howard W. Kerr, Jr., Northeast Regional Director of Small Farms Research, gave in directing the study and designing the questionnaire.

\section{West Virginia University}

Agricultural and Forestry Experiment Station

College of Agriculture and Forestry

Dale W. Zinn, Director

Morgantown

\section{Contents}

Introduction

5

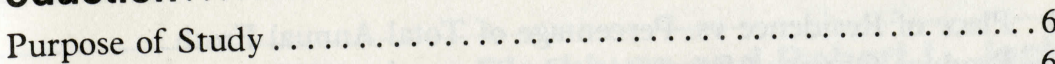

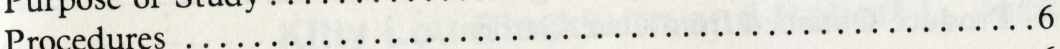

General Summary of Respondents ................... 6

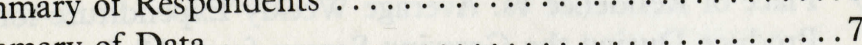

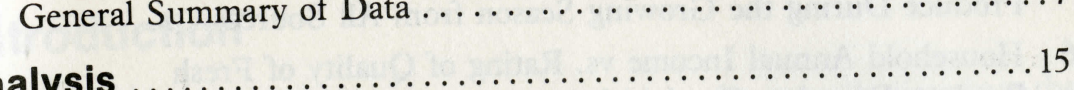

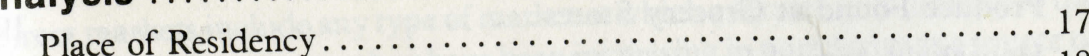

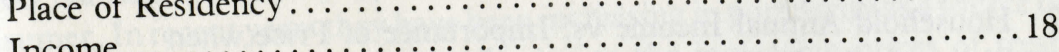

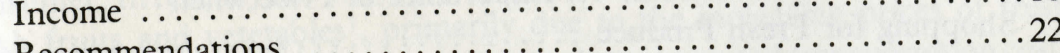

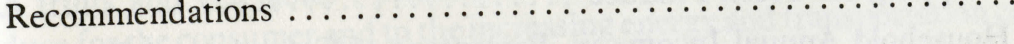

\section{Tables}

1 Rating of the Quality of Fresh Fruits and Vegetables at Direct Markets and at Grocery Stores $\ldots \ldots \ldots \ldots \ldots \ldots \ldots . . .6$.

2 Comparison of Prices at Direct Markets to Those at Grocery Stores ........................

3 Importance of Selected Characteristics when Shopping for Fresh Fruits and Vegetables ................

Fresh Fruits and Vegetables Usually Purchased on a Weekly

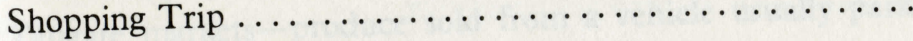

Reasons Given for Shopping at Direct Markets ............. 10

6 Number of Visits Made to Each Type of Direct Market in $1981 \ldots . . . . . . . . . . . . .$.

Round Trip Mileage from Home to Direct Markets at which Respondents Usually Shop......................12

8 Average Expenditure per Visit to Each Type of Direct Market .....13

9 Responses to "We Would Like to Know If There Are any Particular Reasons Why You Haven't Bought Produce at Direct Markets or Even If You Have, Whether You Have Direct Markets or Even Things About Them that You Didn't Like" ............

10 Suggestions for Improvements to Direct Markets 15 
11 Way of First Learning About Direct Markets in Area ......... 16

12 Place of Residence vs. Importance of Quality when Shopping

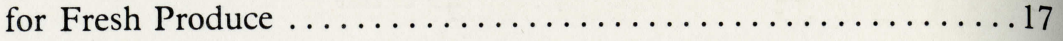

13 Place of Residence vs. Percentage of Total Annual Fresh Produce Purchased from Retail Stores $\ldots \ldots \ldots \ldots \ldots \ldots \ldots \ldots$

14 Place of Residence vs. Percentage of Total Annual Fresh Produce Obtained from Own Garden ....................18

15 Place of Residence vs. Average Weekly Expenditure for Fresh Produce During the Growing Season from All Sources ......... . 19

16 Household Annual Income vs. Rating of Quality of Fresh Produce Found at Grocery Stores ..................... 19

17 Household Annual Income vs. Importance of Price when

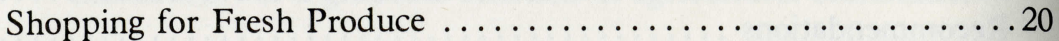

18 Household Annual Income vs. Percentage of Total Annual Fresh Produce Obtained from Own Garden.................. 20

19 Household Annual Income vs. Percentage of Total Annual Fresh Produce Obtained from a Friend's or Neighbor's Garden .......21

20 Household Annual Income vs. Percentage of Total Annual Fresh Produce Purchased from Retail Stores .................. 21

21 Household Annual Income vs. Average Weekly Expenditure on Fresh Produce from All Sources During the Growing Season ......22
Consumers' Opinions, Attitudes and Use of Direct Markets in West Virginia

Kitty Lou Blackburn and Robert L. Jack

\section{Introduction}

Direct markets include any type of market at which a farmer sells directly to the recent years they have been increasing in popularity as a source of fruits and vetetables ${ }^{1}$, primarily due to the increasing prices of fresh produce for the consumer and to the increasing energy and transportation costs for the producers.

more aware of the quality of prices, consumers ans arvey used produce they purchase. According to the consumers answering fhe surver, of higher in this study, produce purchased at direct markets isere. Direct markets allow quality, and at a lower price than may be found elsewhere. Direct markem.

producers to increase their earnings because there are no middement their

Most of the recent direct market studies have dealt with producers and direct

Most of the relating to direct marketing and opinions and attitude markets. Because of this, there is a need for informarkets. This study attempted to their opinions and attitudes and uses of direct markets. Virginia.

provide information about consumets analyzed in this study were:

The four types of direct markets analyzed in this study were: along a

1. Tailgate markets-produce sold from a vehicle usually parked along a highway.

2. Roadside stands-produce sold from some type of permanent structure which is usually located beside a highway.

3. Farmers' markets-producers sell their produce at onte governments, or Such markets may be sponsored by city, county, or state governments, or are operated independently.

the farm

Fresh fruits and vegetables and fresh produce are used interchangeably. 


\section{Purpose of the Study}

1. To identify West Virginia consumer views concerning direct markets.

2. To determine consumer expectations and needs that must be satisfied to make a direct market successful.

3. To use the information obtained as a basis for making recommendations for improving direct markets in West Virginia.

\section{Procedures}

The questionnaire used in this study was developed by a northeastern committee composed of representatives from Delaware, Maine, and Wes Virginia. The same questionnaire was used in all three states in order to make a regional analysis and an analysis for each state possible.

The questionnaire was mailed to 5,000 West Virginia households randomly selected from the telephone directories in all West Virginia cities. The first mailing, also including an introductory letter, was made in November, 1981. Approximately two months later a second mailing of a follow-up letter and another questionnaire was made. Slightly more than 16 percent of the questionnaires were returned and used in the analysis.

Data obtained were summarized and frequency tables developed. Chi square analysis was used to test for significant relationships between selected socioeconomic variables and selected responses to questions. All results were tested at the 5 percent confidence level.

\section{General Summary of Respondents}

Socioeconomic variables used in this study included place of residence, education of person answering survey, occupation of person answering survey, and household total gross income for 1980 .

About 39 percent of the respondents resided in cities, 18 percent in suburbs, 16 percent in towns, and 26 percent in rural areas ( 20 percent rural non-farm and 6 percent rural farm). More than 43 percent of the respondents completed 13 or more years of school. Retired/disabled persons comprised 24 percent; homemakers 18 percent; professional/technical 15 percent; and laborers 10 percent of the respondents. About 6 percent of the respondents had annual incomes of $\$ 5,000$ or less; 29 percent, $\$ 15,000$ to $\$ 24,999 ; 27$ percent, $\$ 25,000$ to $\$ 39,999$; and 9 percent, $\$ 40,000$ or more.

A comparison of the above data with mean levels of income and education in West Virginia suggest that respondents were above state averages for income and education.

\section{General Summary of Data}

The quality of fresh produce at direct markets was considered much better by The respondents than the quality of fresh produce at grocery stores (Table 1). the reson 91 percent ranked quality at direct markets as "Good or Excellent," while only 52 percent ranked quality at grocery stores this high.

Table 1.

Rating of the Quality of Fresh Fruits and Vegetables at Direct Markets and at Grocery Stores

\begin{tabular}{lcccc}
\hline \hline Quality Rating & \multicolumn{2}{c}{ Direct } & Markets & \multicolumn{2}{c}{ Grocery } & Stores \\
\hline & Number & Percent $^{\star}$ & Number & Percent $^{\star}$ \\
Poor & 8 & 1.3 & 41 & 5.5 \\
Fair & 43 & 6.9 & 319 & 42.5 \\
Good & 318 & 51.4 & 344 & 45.9 \\
Excellent & 249 & 40.3 & 46 & 6.1 \\
\hline
\end{tabular}

Percentages were calculated using the total number of respondents for each type of market.

More than half of the respondents believed direct market prices to be lower More than half of than grocery store prices for fresh produce (Tame at direct markets and grocery
respondents believed prices to be about the same

stores.
When shopping for fresh produce, quality was chosen as the attribute considered to be most important by the respondents (Table 3). Appearance and price were the next most important attributes. Where produce is grown was only of minor importance to the respondents.

\section{Table 2.}

Comparison of Prices at Direct Markets to Those at Grocery Stores

\begin{tabular}{lcc}
\hline Response & Number & Percent $^{\star \star}$ \\
\hline Higher & 43 & 8.1 \\
About the same & 171 & 32.3 \\
Lower & 292 & 55.1 \\
Don't know & 23 & 4.3 \\
\hline
\end{tabular}

Only those respondents who had previously shopped at direct markets answered this question. $\star \star$ Percentages were calculated using total number of respondents for the question. 


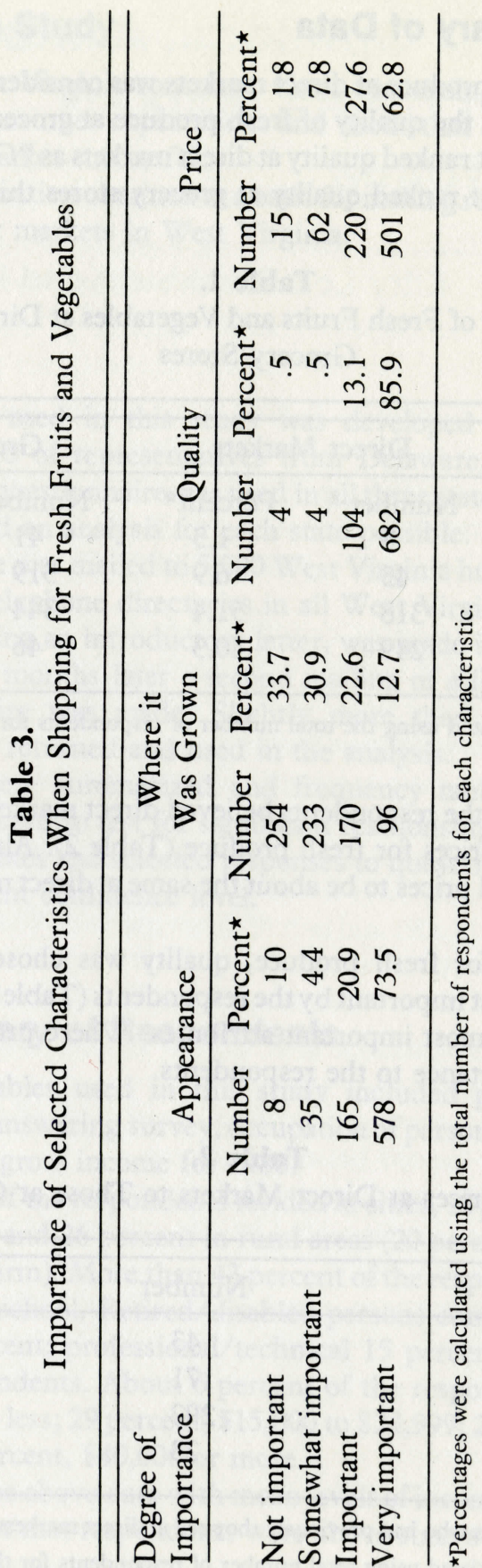

8
On a weekly shopping trip, either to direct markets or grocery stores, the most frequently purchased fresh produce items were apples, lettuce, and (Table 4). Potatoes, roots (turnips/beets/sweet potatoes), cabbage and peppers were not purchased as frequently.

Respondents who had previously shopped at direct markets were asked to (hem. High quality, good prices, convenience, list the farmers, and good variety/volume were some reasons listed (Table like to help farm for pick-your-own operations. Nice 5). Convenience was not rated high for pick-your-own atmosphere was not a strong point for tailgate markets. These respond were also asked several questions about their use of direct in 1981 (Table 6). them made ten or less visits to all types of direct markets in Over a fourth of these respondents made more than ten visits to farmers' markets in 1981. Pick-your-own operations were visited less frequently than the other types of direct markets.

Ext for travel to pick-your-own operations, more than 60 percent of the Except for travel to pick respondents traveled 10 or less miles per round pick-your-own operations traveled A third of the respondents who shopped at pent traveled more than 20 miles per 26 miles or more per round trip

round trip to farmers' markets. Most respondents who shopped at direct of the respondents indicated that $\$ 10.00$ per visit (Table 8 ). Almost 19 percent of the restions.

they spent $\$ 20.00$ or more per visit to pick-your-own operations.

Table 4.

Fresh Fruits and Vegetables Usually Purchased on a Weekly Shopping Trip

\begin{tabular}{lcc}
\hline $\begin{array}{l}\text { Fresh Fruit or } \\
\text { Vegetable }^{\star}\end{array}$ & $\begin{array}{c}\text { Number Purchased } \\
\text { Weekly }(\mathrm{N}=711)\end{array}$ & Percent \\
\hline Apples & 746 & 66.9 \\
Lettuce & 459 & 64.5 \\
Tomatoes & 291 & 40.9 \\
Bananas & 270 & 37.9 \\
Citrus Fruits & 266 & 37.4 \\
Carrots & 217 & 30.5 \\
Potatoes & 166 & 23.3 \\
Roots (Turnips/Beets/etc.) & 135 & 19.0 \\
Cabbage & 118 & 16.6 \\
Peppers & 87 & 12.2 \\
\hline
\end{tabular}

*Respondents could list more than one fresh fruit or vegetable. 

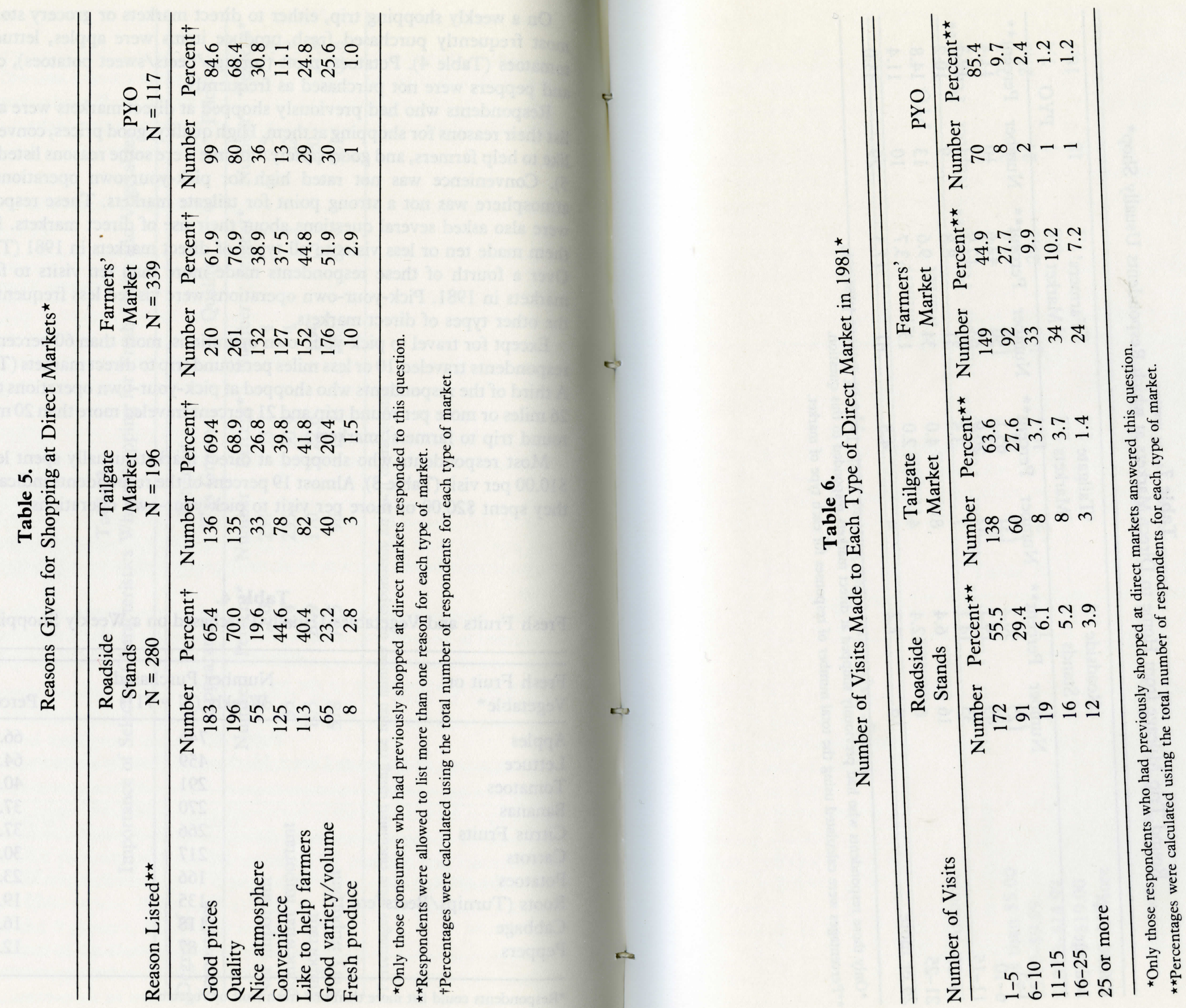


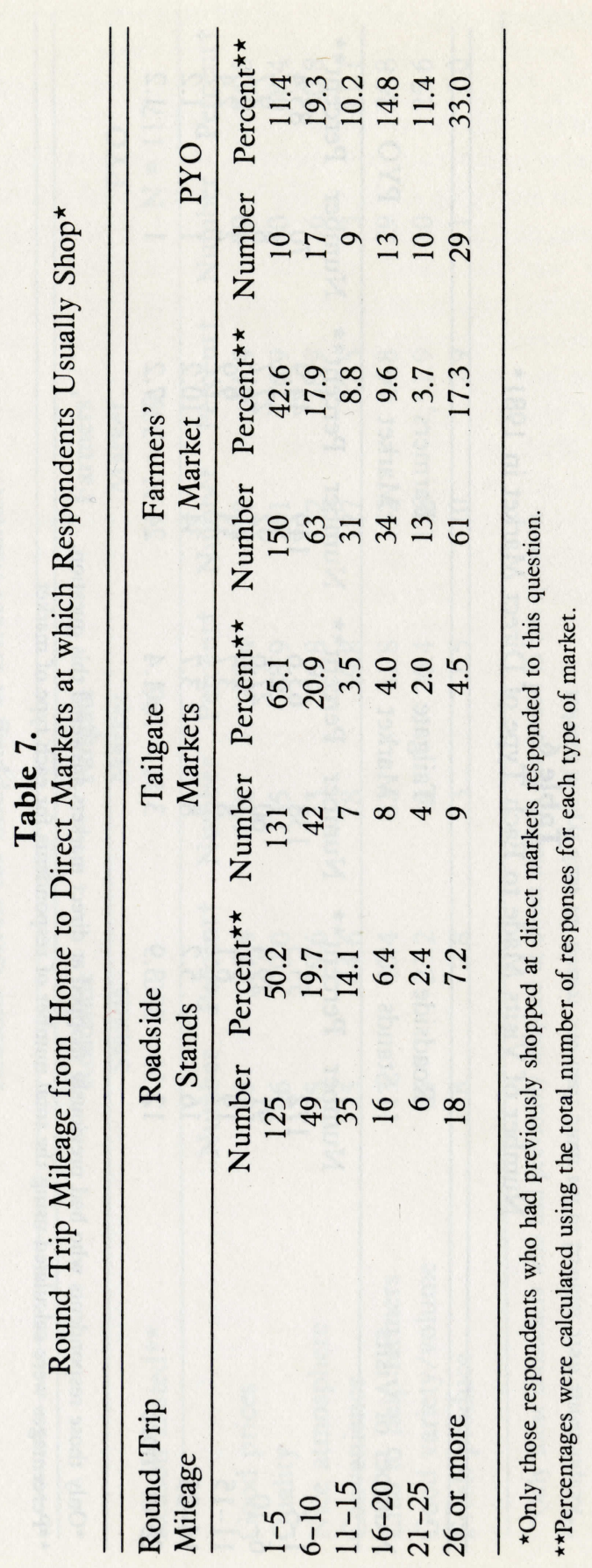

12

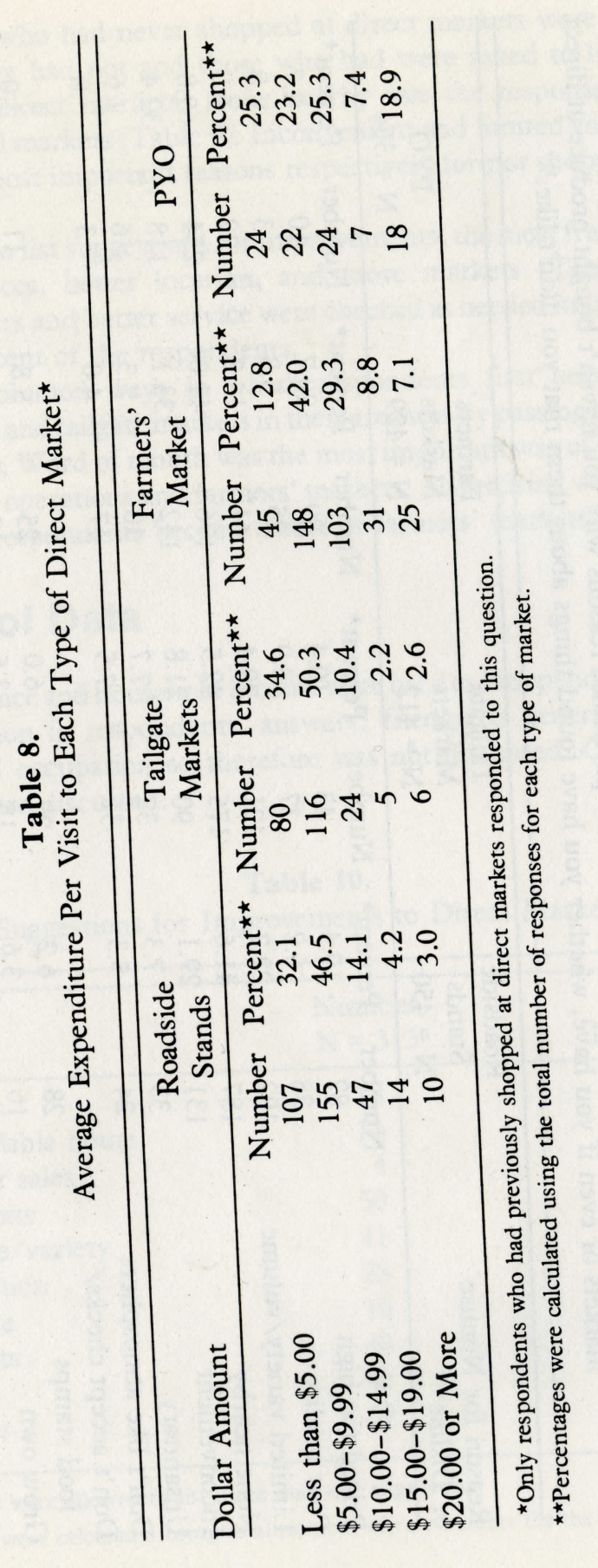

13 


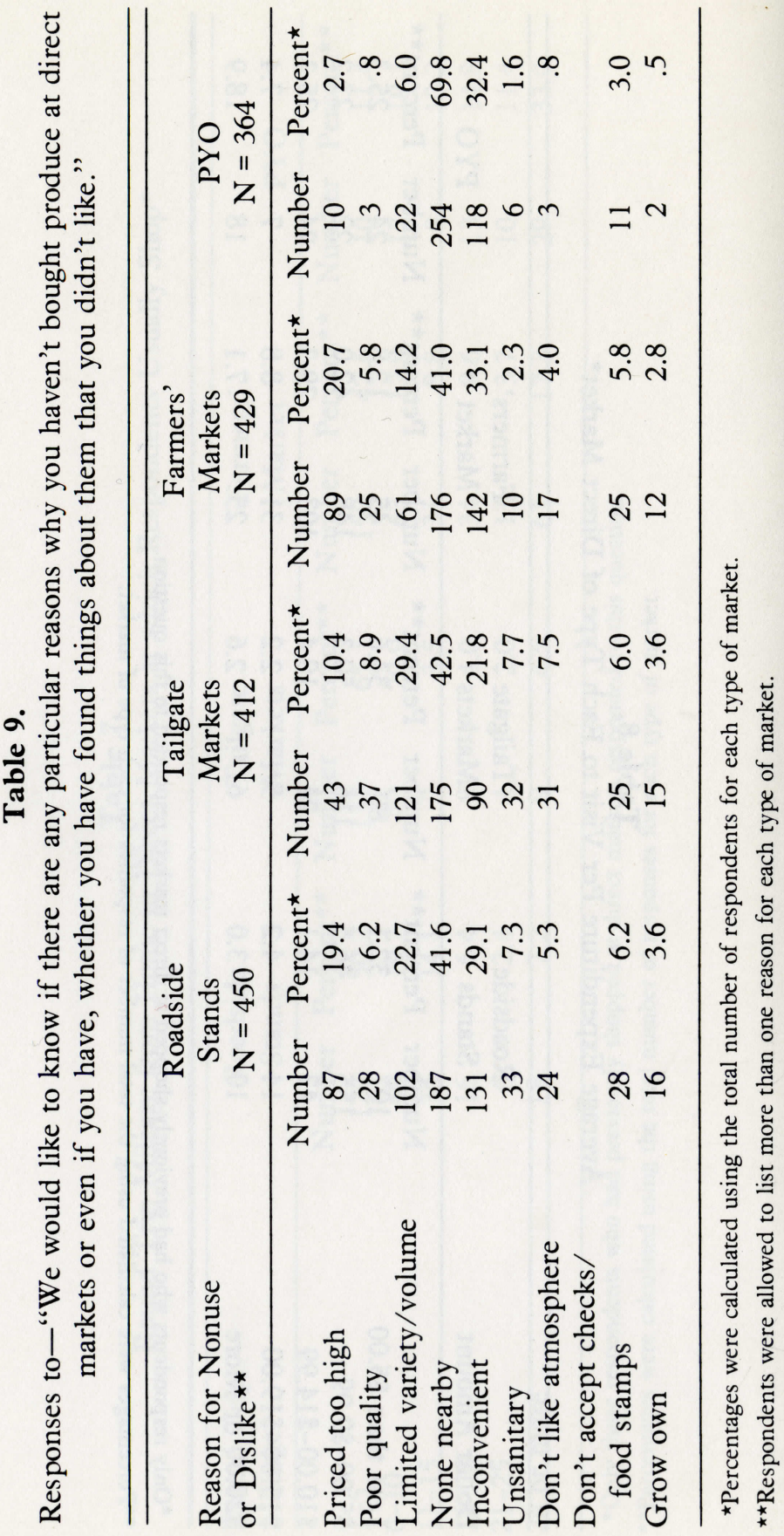

Respondents who had never shopped at direct markets were asked to list Rosons why they here asked to list what they reasons why they had not and those response given most disliked about direct markety frequently for all markets (Tirect were the

Warkets.

When asked to list suggestions for improvements, the most were lower prices, better location, and more markets (Table 10). More dependable hours and better service were

less than 4 percent of the respondents.

The most common ways in which respon the roadside stands and tailgate markets in their area was by passing by them on the road (Table 11). Word of mouth was the most important way of learning about pick-your-own operations and farmers 'markets. Adverting warkets.

a third of the respondents became aware of farmers' markets.

\section{Analysis of Data}

Place of residence and household income were used as independent variables to explain variation in respondents' answers. Income is generally a result of education and occupation so therefore was not discussed. Only significant relationships are discussed.

Table 10.

Suggestions for Improvements to Direct Markets

\begin{tabular}{lcc}
\hline & $\begin{array}{c}\text { Number } \\
\text { Suggestions }\end{array}$ & Percent $^{\star \star}$ \\
\hline Longer hours & 18 & 5.7 \\
More dependable hours & 11 & 3.5 \\
Door-to-door sales & 4 & 1.3 \\
Better locations & 50 & 15.9 \\
More volume/variety & 41 & 13.1 \\
Better sanitation & 25 & 8.0 \\
Better service & 10 & 3.2 \\
More markets & 49 & 15.6 \\
Advertise & 42 & 13.4 \\
Lower prices & 69 & 22.0 \\
\hline
\end{tabular}

$\star$ Respondents were allowed to list more than one suggestion

* 


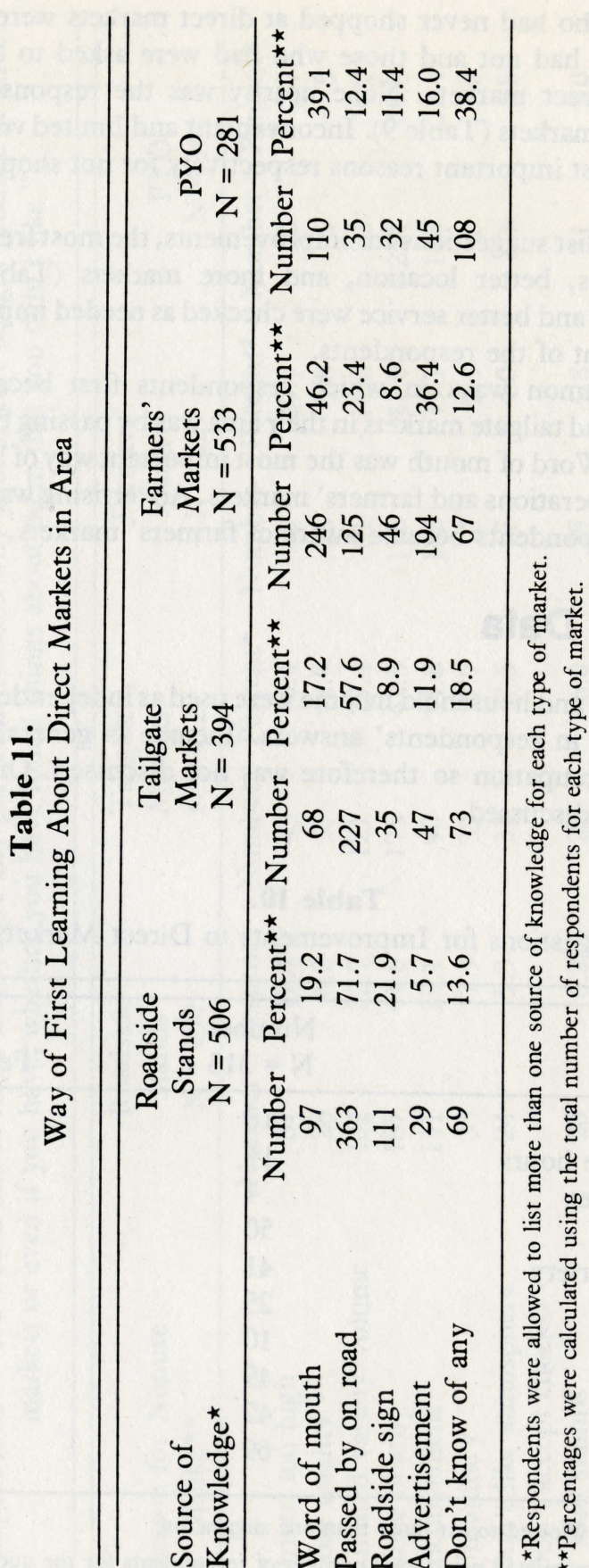

16

\section{Place of Residency}

The percentage of respondents who considered quality a very important attribute when shopping for fresh produce decreased as place of residence became more rural except for rural farm residents (Table 12). Respondents became more rualler percentage of their fresh produce who lived in rural areas purchased a smaller percentage of their fresh produce

Table 12.

Place of Residence vs. Importance of Quality when Shopping for Fresh Produce

\begin{tabular}{lccc}
\hline Residence & Number & $\begin{array}{c}\text { Not Important at All } \\
\text { to Somewhat Important }\end{array}$ & $\begin{array}{c}\text { Very } \\
\text { Important }\end{array}$ \\
\hline \multicolumn{3}{c}{ Percent } \\
City & 258 & 10.1 & 89.9 \\
Suburbs & 122 & 12.3 & 87.7 \\
Town & 108 & 18.5 & 81.5 \\
Rural non-farm & 142 & 20.4 & 79.6 \\
Rural farm & 44 & 15.9 & 84.1 \\
\end{tabular}

Chi Square $=10.000$

$\mathrm{DF}=4$

Prob. $=0.0388$

Table 13.

Place of Residence vs. Percentage of Total Annual Fresh Produce Purchased from Retail Stores

\begin{tabular}{lcccccc}
\hline & & \multicolumn{5}{c}{ Percentage Amount Purchased } \\
\cline { 3 - 7 } $\begin{array}{l}\text { Place of } \\
\text { Residence }\end{array}$ & Number & $10-25$ & $26-70$ & $71-89$ & $90-95$ & $96-100$ \\
\hline & & & 5 & Percent \\
City & 217 & 11.9 & 32.7 & 17.1 & 21.1 & 17.1 \\
Suburban & 102 & 22.6 & 30.4 & 16.7 & 18.6 & 11.8 \\
Town & 88 & 14.8 & 31.8 & 22.7 & 21.6 & 9.1 \\
Rural non-farm & 110 & 35.4 & 31.8 & 16.4 & 11.0 & 5.4 \\
Rural farm & 26 & 50.0 & 23.1 & 15.4 & 7.7 & 3.8 \\
\end{tabular}

Chi Square $=51.059$

$\mathrm{DF}=12$

Prob. $=0.0001$ 
of city, suburban, and town residents purchased more than 70 percent of their fresh produce from retail stores.

Almost half of the rural farm residents obtained 81 to 100 percent of their fresh produce from their own gardens (Table 14). Over 55 percent of city, suburban, and town residents obtained 40 percent or less of their fresh produce from their own gardens.

Expenditures of less than $\$ 11.00$ per week on fresh produce during the growing season was indicated by more than half of the respondents in each place of residence (Table 15). Slightly more than 6 percent of the rural farm residents spent more than $\$ 21.00$ per week while over 18 percent of the town residents spent this amount.

\section{Income}

The percentage of respondents who rated the quality of fresh produce at grocery stores as good increased as income increased except for those in the $\$ 40,000$ or more income level (Table 16). Over half of those in that level of income rated the quality of fresh produce at grocery stores as poor to fair.

As the level of income increased the percentage of respondents rating price as a very important attribute when shopping for fresh produce decreased (Table 17). Almost 24 percent of the respondents with incomes of $\$ 40,000$ or more rated prices as not important at all to somewhat important.

Respondents in the lower income categories obtained more of their fresh produce from their own gardens and friends' or neighbors' gardens than

Table 14.

Place of Residence vs. Percentage of Total Annual Fresh Produce Obtained from Own Garden

\begin{tabular}{|c|c|c|c|c|c|c|}
\hline \multirow{2}{*}{$\begin{array}{l}\text { Place of } \\
\text { Residence }\end{array}$} & \multirow[b]{2}{*}{ Number } & \multicolumn{5}{|c|}{ Percentage Amount } \\
\hline & & $1-20$ & $21-40$ & $41-60$ & $61-80$ & $81-100$ \\
\hline & & \multicolumn{5}{|c|}{ Percent } \\
\hline City & 119 & 50.4 & 16.8 & 14.3 & 10.1 & 8.4 \\
\hline Suburban & 67 & 38.8 & 16.4 & 23.9 & 13.4 & 7.5 \\
\hline Town & 53 & 43.4 & 20.8 & 20.8 & 9.4 & 5.7 \\
\hline Rural non-farm & 105 & 26.4 & 18.1 & 20.0 & 24.8 & 10.5 \\
\hline Rural farm & 42 & 14.3 & 9.5 & 19.1 & 11.9 & 45.2 \\
\hline
\end{tabular}

Chi Square $=71.326$

$\mathrm{DF}=16$

Prob. $=0.0001$
Table 15.

Place of Residence vs. Average Weekly Expenditure for Fresh Produce During the Growing Season from All Sources

\begin{tabular}{lcccc}
\hline & \multicolumn{3}{c}{ Expenditure } \\
$\begin{array}{l}\text { Place of } \\
\text { Residence }\end{array}$ & Number & $\$ 1.00-\$ 10.00$ & $\$ 11.00-\$ 20.00$ & $\begin{array}{c}\$ 21.00 \\
\text { or More }\end{array}$ \\
\hline & & & Percent \\
City & 198 & 58.9 & 27.8 & 13.6 \\
Suburbs & 89 & 52.8 & 37.1 & 10.1 \\
Towns & 65 & 63.1 & 18.5 & 18.5 \\
Rural non-farm & 106 & 68.9 & 16.0 & 15.2 \\
Rural farm & 31 & 64.5 & 29.0 & 6.4 \\
\end{tabular}

\section{Chi Square $=15.742$}

$\mathrm{DF}=8$

Prob. $=0.0462$

Table 16.

Household Annual Income vs. Rating of Quality of Fresh Produce Found at Grocery Stores

\begin{tabular}{lcccc}
\hline & & & Poor to \\
Income & Number & Fair & Good & Excellent \\
\hline & & & Percent & \\
Less than $\$ 10,000$ & 106 & 53.8 & 34.0 & 12.3 \\
$\$ 10,000-\$ 14,999$ & 102 & 51.0 & 44.1 & 5.0 \\
$\$ 15,000-\$ 24,999$ & 197 & 48.7 & 47.7 & 3.6 \\
$\$ 25,000-\$ 39,999$ & 180 & 44.4 & 50.6 & 5.0 \\
$\$ 40,000$ or more & 57 & 50.9 & 47.4 & 1.8 \\
\end{tabular}

Chi Square $=17.657$

$\mathrm{DF}=8$

Prob. $=0.0240$

respondents with higher incomes (Tables 18 and 19). Over 58 percent of the respondents with incomes of $\$ 40,000$ or more obtained 20 percent or less of their own gardens. Almost 28 percent of the their fresh product of $\$ 10,000$ or less obtained over 80 percent of fresh produce from their own gardens. Over $3 / 4$ of the respondents with 
Table 17.

Household Annual Income vs. Importance of Price when Shopping for Fresh Produce

\begin{tabular}{|c|c|c|c|c|}
\hline Income & Number & $\begin{array}{l}\text { Importance } \\
\text { Not Important at All } \\
\text { to Somewhat Important }\end{array}$ & $\begin{array}{l}\text { of Price } \\
\text { Important }\end{array}$ & $\begin{array}{l}\text { Very } \\
\text { Important }\end{array}$ \\
\hline & & \multicolumn{3}{|c|}{ Percent } \\
\hline Less than $\$ 5,000$ & 42 & 2.4 & 21.4 & 76.2 \\
\hline$\$ 5,000-\$ 9,999$ & 80 & 5.0 & 23.8 & 71.3 \\
\hline$\$ 10,000-\$ 14,999$ & 105 & 11.4 & 22.0 & 66.7 \\
\hline$\$ 15,000-\$ 24,999$ & 206 & 7.3 & 31.1 & 61.6 \\
\hline$\$ 25,000-\$ 39,999$ & 184 & 10.3 & 35.3 & 54.4 \\
\hline$\$ 40,000$ or more & 59 & 23.7 & 32.2 & 44.1 \\
\hline
\end{tabular}

\section{Chi Square $=31.876$}

$\mathrm{DF}=10$

Prob. $=0.0004$

Table 18.

Household Annual Income vs. Percentage of Total Annual Fresh Produce Obtained from Own Garden

\begin{tabular}{lrrrrrr}
\hline & & \multicolumn{5}{c}{ Percentage Amount } \\
\cline { 3 - 7 } Income & Number & $0-20$ & $21-40$ & $41-60$ & $61-80$ & $81-100$ \\
\hline & & & \multicolumn{5}{c}{ Percent } \\
Less than $\$ 10,000$ & 61 & 19.7 & 14.7 & 23.0 & 14.8 & 27.8 \\
$\$ 10,000-\$ 14,999$ & 62 & 30.6 & 17.7 & 30.6 & 9.7 & 11.3 \\
$\$ 15,000-\$ 24,999$ & 136 & 41.2 & 16.9 & 16.2 & 16.9 & 8.8 \\
$\$ 25,000-\$ 39,999$ & 58 & 39.6 & 17.7 & 13.5 & 18.8 & 10.4 \\
$\$ 40,000$ or more & 31 & 58.1 & 16.3 & 16.1 & 3.2 & 6.4 \\
\hline
\end{tabular}

Chi Square $=37.277$

$\mathrm{DF}=16$

Prob. $=0.0019$

incomes of $\$ 25,000$ or more obtained 1-10 percent of their fresh produce from a friend's or neighbor's garden.

Over half of the respondents in the income category of less than $\$ 5,000$ and with incomes of $\$ 25,000$ or more purchased more than 70 percent of their fresh
Table 19.

Household Annual Income vs. Percentage of Total Annual Fresh Produce Obtained from a Friend's or Neighbor's Garden

\begin{tabular}{lccc}
\hline & & \multicolumn{2}{c}{ Percentage Amount } \\
\cline { 3 - 4 } Income & Number & $1-10$ & Greater than 10 \\
\hline & & & Percent \\
Less than $\$ 5,000$ & 13 & 53.8 & 46.2 \\
$\$ 5,000-\$ 9,999$ & 27 & 37.0 & 62.9 \\
$\$ 10,000-\$ 14,999$ & 36 & 36.1 & 63.9 \\
$\$ 15,000-\$ 24,999$ & 91 & 60.4 & 39.6 \\
$\$ 25,000-\$ 39,999$ & 84 & 75.0 & 25.0 \\
$\$ 40,000$ or more & 21 & 76.2 & 5.0 \\
\end{tabular}

Chi Square $=24.926$

$\mathrm{DF}=6$

Prob. $=0.0001$

produce from retail stores (Table 20). More than half of the respondents with promes between $\$ 5,000$ and $\$ 24,999$ purchased 70 percent or less of their fresh produce from retail stores.

Table 20.

Household Annual Income vs. Percentage of Total Annual Fresh Produce Purchased from Retail Stores

\begin{tabular}{|c|c|c|c|c|c|c|}
\hline \multirow[b]{2}{*}{ Income } & \multirow[b]{2}{*}{ Number } & \multicolumn{5}{|c|}{ Percentage Amount } \\
\hline & & $1-25$ & $26-70$ & $71-89$ & $90-95$ & Over 95 \\
\hline & & & & Percent & & \\
\hline Less than $\$ 5,000$ & 22 & 13.6 & 18.2 & 22.7 & 27.3 & 18.2 \\
\hline$\$ 5,000-\$ 9,999$ & 53 & 24.5 & 32.1 & 9.4 & 11.3 & 22.6 \\
\hline$\$ 10,000-\$ 14,999$ & 80 & 18.8 & 37.5 & 21.2 & 8.8 & 13.8 \\
\hline$\$ 15,000-\$ 24,999$ & 173 & 35.4 & 32.4 & 17.3 & 19.6 & 5.2 \\
\hline$\$ 25,000-\$ 39,999$ & 164 & 20.1 & 28.7 & 17.7 & 20.7 & 12.8 \\
\hline$\$ 40,000$ or more & 51 & 11.7 & 33.3 & 19.6 & 21.6 & 13.7 \\
\hline
\end{tabular}

Chi Square $=30.997$

$\mathrm{DF}=20$

Prob. $=0.0552$ 
Respondents in the lower income levels generally spent less on fresh produce (at grocery stores and direct markets) during the growing season than those with higher incomes (Table 21).

\section{Table 21.}

Household Annual Income vs. Average Weekly Expenditure on Fresh Produce from All Sources During the Growing Season

\begin{tabular}{lcccc}
\hline Income & Number & $\$ 1.00-\$ 10.00$ & $\$ 11.00-\$ 20.00$ & $\begin{array}{c}\$ 21.00 \\
\text { or More }\end{array}$ \\
\hline $\begin{array}{c}\text { Less Than } \\
\$ 5,000\end{array}$ & 27 & 64.7 & Percent & \\
$\$ 5,000-$ & 50 & 72.0 & 23.5 & 11.7 \\
$\begin{array}{l}\$ 9.999 \\
\$ 10,000-\end{array}$ & 62 & 67.7 & 20.0 & 8.0 \\
$\$ 14,999$ & 159 & 66.7 & 24.2 & 8.1 \\
$\begin{array}{c}\$ 15,000- \\
\$ 24,999\end{array}$ & 153 & 52.9 & 28.1 & 9.4 \\
$\begin{array}{c}\$ 25,000- \\
\$ 39,999\end{array}$ & 48 & 43.7 & 33.3 & 18.9 \\
$\begin{array}{c}\$ 40,000 \text { or } \\
\text { more }\end{array}$ & & & & 22.9 \\
\hline
\end{tabular}

Chi Square $=19.655$

$\mathrm{DF}=10$

Prob. $=0.0325$

\section{Recommendations}

There is room for expansion and improvement of direct markets in West Virginia. Producers need to be made aware that direct markets could be a viable alternative for marketing fresh produce and consumers need to be aware that they could be an alternative to retail stores.

To increase consumer use of direct markets, consumers must know that such markets exist. This could be done through newspaper and radio advertising carrying such information as location of the market, hours of operation, type of produce available, and some sample prices.

The locations of the markets (except for PYOs) should be convenient to consumers, such as near supermarkets or malls, on regularly traveled roads, on town squares that permit such marketing, and near recreation areas such as lakes and parks.

The producer also needs to be sure that his market is sanitary and is in The producer also needs to regulations governing such marketing. The produce should be displayed neatly, be clean and out of the sun if possible. If produce is being sold from a vehicle, the vehicle should also be clean. The sellers should also be clean, neat, and courteous. This may lead to return visits by consumers and good word-of-mouth advertising.

If possible, the volume and variety needs to be adequate. One way this might be done is by having one seller sell for several producers. Farmers' markets also allow for increased volume and variety because there are several producers selling different items at one location.

Direct markets are used more by city and suburban residents than by rural residents, probably because some rural residents grow most of their own produce. Rural residents should be made aware that they can also benefit by using direct markets. Many of them grow more than they need. They could sell using direct markets. Many of through direct markets. This would give them extra income, and would also be beneficial to urban residents who would have more high quality produce available to them.

\section{Summary}

Direct markets include any type of market at which a producer sells directly to the consumer. In recent years the popularity of direct markets has been increasing. Few direct market studies have focused on consumers and their opinions and attitudes relating to direct markets. In this study, 5,000 randomly selected West Virginia households were mailed questionnaires which 
contained questions about their opinions and attitudes relating to direct markets. Slightly more than 16 percent of these were returned and used in the analysis.

Most of the respondents were favorable toward direct markets in West Virginia. They believed such markets to be a source of fresher, higher quality produce at a lower price than could be found in grocery stores. Respondents were willing to travel further to farmers' markets and pick-your-ownoperations and generally spent more per visit at them than the other types of direct markets. When analyzing the effects of income and place of residence on respondents' use of direct markets it was found that consumers with higher incomes generally made more use of direct markets than those in lower income levels. Respondents who reside in rural areas make less use of direct markets than urban residents. Rural residents also generally spend less per year on fresh produce than residents in other areas.

This study showed that there is a place for direct markets in West Virginia but that consumers and producers both need to be made more aware of them in order to benefit more from them. 